\title{
Well-being, Values, Culture and Society
}

\subsection{The Relationship Between Culture AND WELL-BEING}

For many the arts are a real source of happiness, joy, fun, relaxation and learning. (The Director of Research at Arts Council England [Bunting 2007a, 4])

A wider definition [of wealth], associated with Ruskin, sees a nation's wealth as including personal happiness and fulfilment. It's an obviously broader view, into which culture fits more readily. (Secretary for Culture, Media and Sport [Jowell 2004, 8])

to maximise and exploit the contribution of the arts to core policies including education, health, crime, regeneration and the well-being of the population at large. (Funding agreement between Arts Council England and the Department for Culture, Media and Sport, ${ }^{1}$ April 2003-March 2006 [DCMS 2003a, 15])

In 2007 the Director of Research at Arts Council England (ACE) reported on phase one of its first ever 'public value ${ }^{2}$ enquiry' (Bunting 2007a). The Arts Debate gathered data from nearly 1700 contributions to workshops, in-depth interviews, discussion groups, 'deliberation' and 'open space' meetings and web discussions (Bunting 2007b, 4-5). The first of the above quotes is from one of the reports: Stage one findings and

(C) The Author(s) 2021

S. Oman, Understanding Well-being Data, New Directions in Cultural Policy Research, https://doi.org/10.1007/978-3-030-72937-0_6 
next steps. It argues that the data collected in the Arts Debate prove that the arts are a source of different aspects of well-being, many of which we have already encountered in this book. If this is the case, then these data are useful for understanding how people feel about the arts, as well as how they feel about well-being.

The argument in the above quote from the Arts Debate report recalls the words of utilitarian philosopher Jeremy Bentham that we have encountered before: that the most happiness of the most people should be the aim of policy. By extension, it could be argued that if the arts are a source of happiness for many, then they are important to policy about well-being. The Research Director's statement seems to be a clear assertion of the utility of the arts to people. This 'public value enquiry' was a data gathering exercise to understand the value of the arts to people in the UK, to enable arguments for value in these terms. In cultural policy, 'culture' tends to refer to 'the arts' by default, and this is reinforced through institutions like $\mathrm{ACE}$ and activities like this. The report conjures up a relationship between culture and well-being that, even if unconsciously, is reinforced by drawing on a philosophical grounding. This relationship and the ideas behind it have become naturalised and popularised over time and are used to describe how the arts can improve life, theoretically and practically.

Three years prior to the Arts Debate, Tessa Jowell, the then Secretary for Culture, Media and Sport, published a personal essay called Government and the Value of Culture (2004). In this essay, also quoted above, utilitarianism is referenced directly before nineteenth-century thinker, John Ruskin (who is renowned for his thoughts against utility). Jowell paraphrases John Ruskin, stating that a nation's wealth should include personal happiness. Here, the culture secretary is very consciously explaining that this idea of the good society shows us how culture can demonstrate its value. Crucially, Jowell articulates the value of Ruskin's view: 'because culture fits', and 'readily', therefore cementing culture's public role. The relationship between culture and well-being, or, more specifically, the appetite to prove this relationship, is particularly hungry for well-being data, whilst also producing much well-being data itself. It is, therefore, a good case study for this book, which we will examine further in Chaps. 7 and 8.

This chapter looks at the relationship between culture and well-being to uncover the background to its reliance on data. It sets out the context and arguments behind the subsequent individual data case studies in Chaps. 7 and 8. Establishing 'the culture-well-being relationship' in this chapter enables three things. First, it illustrates the role of well-being data in policy evaluation by focussing on one policy sector. Second, it helps us 
expand on the political economy of data and data practices that we have encountered in Chap. 5. Third, it explores the specific dynamics of the economy of well-being data in a policy sector where few who work inside it consider themselves adept at data (as discussed in the Preface and Chap. 1), despite their reliance on them.

The quotes that open this chapter present evidence of how the 'culturewell-being' relationship is invoked and has become naturalised, particularly in the UK. By this I mean, there is a generally accepted view that culture (broadly defined) is good for well-being (broadly defined). We look at the lineage of this idea as something that began with philosophers and is now common sense; naturalised over time and then popularised. More specifically, these two examples from cultural policy-makers demonstrate how the relationship is operationalised ${ }^{3}$ (put to use) to argue the value of culture.

We will see how this operationalisation means that these ideas can easily be co-opted to argue that culture should be included in delivering social aims. Good social policy is arguably entirely reliant on appreciating the cultural specificities of communities and broader society. However, this meaning of culture, as 'ordinary, in every society and every mind' (Williams [1958] 1989a, 4), is different from that meaning of culture which defaults to that of 'the arts' sought by the Arts Debate. We have acknowledged the slippage between definitions and ideas of well-being (happiness, quality of life, the good society, etc.) in previous chapters and will pay similar attention in terms of culture here. This slippage in meaning can be useful in arguments that defend the utility of culture as good for society. As we discover in Chaps. 7 and 8, this is important when looking at uses of wellbeing data.

This process is often called instrumentalisation ${ }^{4}$ (Gibson 2008; Hadley and Gray 2017; Belfiore 2012) and involves 'culture' being used as a means or 'instrument' for attaining goals in other areas of society, or what are sometimes called policy areas or domains. Examples can be found in policy documents (as we have seen at the beginning of this chapter), research agendas, strategies and practitioner movements, such as the 'arts in health' movement (ACE 2007; AHRC 2021; AHSW n.d.) or the area of culture in regeneration (DCMS 2004; LGA 2020; UNESCO 2018). What we have seen through this ongoing period of instrumentalisation is the idea that the arts can be used to directly address societal problems, leading to the argument that culture is, in fact, instrumental to these social policy areas. Indeed, policy documents have argued that arts are so helpful 
in delivering positive health outcomes that they recommend that health and social care professionals should be trained in arts-based approaches (All-Party Parliamentary Group on Arts, Health and Wellbeing 2014).

This principle-that the arts are instrumental in delivering broader social projects and improving social infrastructure-has in turn been operationalised to advocate for funds for the arts, as part of making the case for the instrumental value of culture. This has shifted the idea of the value of culture from something belonging to everyone (Williams [1958] 1989a; Keynes 1945), to something that is valued for its social impact or for its economic contribution (Campbell 2019; DCMS 2011; National Endowment for the Arts 2018). In arguing this case, the sector is increasingly required to evaluate how much of this additional value it has generated in response to funding; for example, in the 2003 funding agreement between ACE and the government (cited above) there is a commitment to a contribution across various social policy areas as well as the 'well-being of the population at large' (DCMS 2003a, 15).

This is why the cultural sector requires evidence. It has become increasingly reliant on data for these arguments, often requiring metrics as proof. As we go on to discover, the sector is dependent on commissioning research to articulate its value, owing to gaps in data skills and resource as touched on in Chap. 1, and which this book aims to help address.

Box 6.1 The Culture-Well-being Relationship

Theorised $\rightarrow$ naturalised $\rightarrow$ popularised $\rightarrow$ operationalised $\rightarrow$ instrumentalised $\rightarrow$ operationalised $\rightarrow$ metricised $\rightarrow$ capitalised

The values of 'a good society', and the idea that culture is intrinsic to them, have become amalgamated into the process of valuation, which has evolved into a form of proof along the way. As Box 6.1 represents, the processes of theorising and naturalising the relationship, to operationalise this idea, have led to a need to prove this relationship exists. In turn the symbolic value of this proof to the cultural sector means that well-being data now have a financial value, and those who can work with well-being data are able to capitalise on this (Oman and Taylor 2018). This slippage of the meanings of value, values and valuation is part of the cultural value debate $^{5}$ that we introduce in this chapter.

The 'slippery' nature of culture is revealed by how the term is defined and then used. Culture can be described as something more ordinary 
(Williams [1958] 1989a), all around us and in everything we do, but the same term can be used to justify the funding of artforms which are anything but ordinary, with often small numbers of people interested in participating on rare, special occasions. Culture is such a 'complicated word' (Williams [1976] 1988, 87) that it makes it difficult to write about the culture-well-being relationship. However, we can see this ambiguity operationalised, as some arguments for the value of culture will refer to broader ideas of culture, when they are arguing for the arts, as we shall see in later chapters.

As described in Chap. 1, change is seen in data, but felt in culture. In the culture-well-being relationship, data are used to ascribe value and culture is where values manifest. Recognition of the increasing value of data tends to focus on the scale of Big Data and the human rights issues of personal data. Whilst important, the effects of the fetishisation of data we have encountered throughout this book are also felt in smaller data projects highlighting the need for skills and literacy in social and cultural policy. This chapter establishes two things: first, the relationship between culture and well-being and its association with data and, second, the explanation as to why there is a market for well-being data and analysis in cultural policy as a form of social policy.

\section{Well-being and Culture: Reviewing the Long Theoretical Lineage}

to increase the happiness of men by giving them beauty and interest of incident to amuse their leisure, and prevent them wearying even of rest, and by giving them hope and bodily pleasure in their work; or, shortly, to make man's work happy and his rest fruitful. (William Morris, Aims of Art lecture, 1887, in Belfiore and Bennett 2008, 144)

The aims of art, according to William Morris, should be to improve 'man's' quality of life in numerous ways. The role of culture (broadly defined) in a 'good society' has a long history that can be traced back to ancient Greece. Culture tends to be presented in a positive light, and Aristotle's name tends to be attached to this representation. As you may remember from Chap. 2, many theoretical lineages of ideas of well-being and its measurement for policy derive from Aristotle. Yet, these ideas are not without problems when viewed from contemporary society ${ }^{6}$ and the representation of the culture-well-being relationship as a positive one also requires context. 
The theoretical lineage that culture is vital to a good society actually began in Aristotle's 'counterargument' to Plato. Plato asserted the arts were, in fact, corrupting (Belfiore and Bennett 2008, 39). This reframing of the 'honourable and dishonourable intellectual history of the arts' (Belfiore and Bennett 2008, 10) demands attention if we are to consider the culture-well-being relationship, which leans on this moment in its historical tradition.

Theories of the arts' 'deeply transformative effects for the individual and society' (Belfiore and Bennett 2008, 10) are now an assumed truth that has become naturalised and popularised. However, when this assumption is drawn on, it is the positive effects which are referred to. The noted 'dishonourable' and negative outcomes are conveniently discarded and often forgotten, especially in discussions about what culture is for and in cultural policy.

The cultural sector 'believes that it makes a real difference to people's lives' (NMDC, undated in Selwood 2010,4) and in recent decades much effort has gone into investigating the sector's impact on individuals and how this might play out in communities, societies and nations. So intrinsic is the idea that arts are a social good, that evidence suggests cultural managers believe the sector is good for other people, even if they do not like certain artforms themselves (Stevenson 2019). Here, we will look at specific aspects of subjective well-being (happiness or feeling that life is worthwhile). We know from previous chapters that these have different theoretical lineages and subtle differences in meaning, and so how they appear in cultural policy documents warrants a revisit, before contemplating what is being captured when using data to understand or measure an aspect of well-being.

For example, Dame Liz Forgan suggested that the arts can 'cheer us up' and create forms of 'escape, comfort, understanding and reference in tough times' (ACE 2009, 3). Forgan, who became the first female chair of ACE the same year, echoes the German philosopher (dubbed the artists' philosopher) Arthur Schopenhauer's ([1818] 2000) ideas of the aesthetic experience as protective from the anguish of the human condition. Schopenhauer believed that as understanding and experience of the world develop, we experience pain and responsibility. He felt it was important for the individual to escape certain pressures of communal responsibility, and therefore this was a purpose for the arts.

To contextualise the chair of ACE's comments, she speaks from what we then thought were tough times: the immediate aftermath of financial 
crisis (the 2007/2008 crash). Reflecting on Schopenhauer's idea that we sometimes need to shield ourselves from tough times might cause us to reflect on who Forgan means by 'us', particularly in tension with the communal responsibilities we might want shielding from. This function of the arts-as tonic in times of difficulty-is also related to rejecting struggle. As Belfiore and Bennett (2008) point out, Schopenhauer's meaning of will remains contested, but they conclude (via Janaway 1994, 6) that 'the best way to understand the concept of "will" is to conceive it as a form of unrelenting yet blind "striving forward" for something' (Belfiore and Bennett 2008, 93-95). Does art, therefore, offer a way out of contemporary life's relentless impetus to strive forward? If so, how might these ideas of the importance of art for well-being intersect with the version of well-being as a balance of pleasure and purpose that is introduced in Chap. 2? Perhaps art allows us to escape our own will and the will of society, to be immersed in something else. Yet, this also presents a tension between the social responsibility that is implicit in culture's role in a good society and aesthetic pleasure as an escape from feeling these pressures personally.

Schopenhauer's thinking builds on that of another German philosopher, Emmanuel Kant. For Kant, aesthetic pleasure lies within the process or state of understanding. More specifically, once the aesthetic experience has captured the imagination, it enables greater insight and meaning, and this is pleasurable. Perhaps for Forgan, this is the understanding we are also able to refer back to from tough times?

Yet again there are contradictions, as the pleasure from aesthetic experiences is found in the striving for personal enlightenment. According to Kant, such awareness can only be found while in a balanced state: some sort of equilibrium of the senses. If this has been achieved, then it is possible to experience the 'enjoyment of wellbeing', but only following feeling stirred by 'the play of affects' (Kant [1790]1987, 134, cited in Belfiore and Bennett 2008, 86). Another way of looking at this is that Kant's thinking on hedonism is not about a moment of extreme pleasure (or indeed the chasing of a series of pleasures), but appreciating a moment of satisfaction, which comes after specific kinds of pleasure that lead to enlightenment. For Kant, then, it is important to recognise the feeling of satisfaction that follows this pleasure as a change in well-being.

This is starting to sound more like the language of the happiness economists from Chap. 4 who want to measure subjective well-being as an experience. However, based on this highly simplified version of Kant, the well-being caused by aesthetic pleasure (whether in a park, or in a theatre) 
is not a single effect, but a series of effects that happen over time. When relying on the theoretical lineages of well-being, it is important to consider that they do not always map neatly onto the concepts that economists are hoping to operationalise. This is also true for the culture-well-being relationship, and its inherent assumption that all forms of culture (or any of its chosen sub-categories, whether art, leisure, singing, food, travel) can contribute to all forms of well-being (whether they are physical health, fun, enlightenment, relaxation, empathy, escapism, social responsibility etc.).

As a result, discussion of what culture is, who it is for and how it can be instrumentalised tend to be stuck in a cyclical debate, much like the arguments performed to an audience 2000 years ago by our learned friends Plato and Aristotle in the School of Athens. As with the Arts Debate, consideration of what culture $i$ s or what it is for often merges with articulations of the value of culture (and often as the arts). By extension, these discussions segue into advocacy, for investment in culture as a good choice for social policy (as with the public consultation on public value referred to above) or into debates over how investment is distributed as a public service. We will return to this latter point, but first we need to establish how cultural policy became a form of social policy.

\subsection{Cultural Policy as Social Policy \\ Cultural Policy: Operationalising the Question 'What Is Culture?'}

Taking now the point of view of identification, the reader must remind himself as the author constantly has to do, of how much is here embraced by the term culture. It includes all the characteristic activities and interests of a people; Derby Day, Henley Regatta, Cowes, the twelfth of August, a cup final, the dog races, the pin table, the dart board, Wensleydale cheese, boiled cabbage cut into sections, beetroot in vinegar, nineteenth-century Gothic churches and the music of Elgar. The reader can make his ${ }^{7}$ own list. And then we have to face the strange idea that what is part of our culture is also part of our lived religion. (T.S. Eliot, Notes Towards a Definition of Culture [1948] 1973)

In cultural policy, 'culture' tends to refer to 'the arts' by default. There are many books which consider questions of culture and many 'men of letters' have concerned themselves with its definition, with Raymond Williams 
and poet T.S. Eliot some of the most quoted. Understanding culture is more complicated than thinking of its definition and devising lists of what it is, however. Williams and his fellow cultural studies scholars' work on culture explains far more than its definition. Williams attempts to capture how meanings and values interact across society (1977); what he famously called 'our modern structure of meanings' ([1958] 1989a, xiii), incorporating the institutions which manage our quality of life. He is interested in how ideas of 'continuity' are determined by certain groups which define 'the tradition'. ${ }^{8} \mathrm{He}$ continues that it is 'the tradition' of certain groups that gets to decide what culture is ([1961] 1971, 66), and what culture will continue to be. By extension, this means that only certain people get to define culture and its role in society, as an ongoing process that repeats itself.

The definition and management of culture might make you think of some of the issues we have encountered with well-being data, particularly the penultimate section of Chap. 3. Some people get to define what they think well-being is, and what should be measured, using particular data. This essentially defines well-being, well-being data and their role in society, but also how society is managed. For Williams, the way well-being, data and culture are organised is vital to how society works, and we need to understand them all together.

Williams offers us more than a definition of culture. He presents a theory of culture, to deepen understanding of how culture works ([1961] 1971). He argues that to develop an understanding of culture and society, we need to incorporate and deepen:

analysis of elements in the way of life that to followers of the definition are not "culture" at all: the organisation of production, the structure of the family, the structure of institutions which express or govern social relationships [and] the characteristic forms through which members of the society communicate. ([1961]1971, 57-58)

What he means by this is that if we want to understand culture and how it works in society, we need to look at all of the stuff around it: how it is organised, communicated and managed-in the context of how other social structures work.

A simpler way of describing this, and why it is important here, is that: to understand culture and society, we need also to understand social policy and governance in general, as well as the institutions that organise and manage them. This includes appreciating how social policy works on 
society, or its effects, alongside the ways that this happens. Also, good social policy and governance require a better understanding of culture and society. ${ }^{9}$ Therefore, society and social policy-and culture and cultural policy-are interlinked and need to be understood together, and within the context of the ways they are organised. Furthermore, this book argues that data are cultural, and so we cannot fully understand well-being data without appreciating both society and culture and, as Williams explains, the institutions which manage them.

\section{Cultural Policy: Institutions for Well-being}

It was the task of C.E.M.A. [Council for the Encouragement of Music and the Arts] to carry music, drama and pictures to places which would otherwise be cut off from all contact with the masterpieces of happier days and times: to air-raid shelters, to war-time hostels, to factories, to mining villages. (John Maynard Keynes 1945)

The naturalised relationship between culture and well-being is a consequence of the theoretical lineage of ideas of the good society we touched on above. The culture-well-being relationship has subsequently been operationalised through cultural policy as social policy in numerous ways. The above quote is from John Maynard Keynes, a key figure in economics, whose developments still inform much government policy today. Keynes invokes the culture-well-being relationship here, by describing what would happen without its preservation. He paints a mental picture where cutting off miners from masterpieces jeopardises their happiness, as that is how they access memories of happier days.

For the Victorians, the arts and culture were considered 'elevating and refining to the working man' (Bennett 2000, 1414). Public cultural institutions were established 'to resolve problematic class behaviours', with Henry Cole advocating in 1884 that 'museums should go into competition with the Gin Palaces' (cited in Bennett 2000, 1414), as 'the rapt contemplation of a Raphael' would keep wayward husbands from the taproom (contemporary magazine [1858], cited in Bennett 2000, 1414). Even the public park emerged for those who migrated to cities during the Industrial Revolution (Gilmore and Doyle 2019). In other words, the park as we now know it was another Victorian strategy for the improvement - and regulation — of urban populations.

When culture is categorised as a solution for society, the idea is then developed and operationalised, and presented as a way to restore some form of social balance; whilst recognising that museums are in 
competition' with other ways of spending time, whether a park or a pub. Identifying problematic aspects of society and their associated pastimes has been long entwined with ideas that certain activities, and therefore the people that do them, are deficient, and lacking in the right sort of culture, or are 'uncultured'. People may lack a link to masterpieces of the past, but that does not mean that they lack culture, are 'cut off from it' or are indeed less happy as a result.

People in fact choose to not seek links to the culture described as a masterpiece and find happiness in pastimes that may suit them better. This approach to managing society by addressing the ways in which certain people 'lack' a certain kind of culture is called a 'deficit model'. It stigmatises the practices of some people, and not others, the belief being that if certain people only engaged in a particular form of cultural participation, in the same way as these other, more exemplary people do, then we could be closer to 'a good society'. This model of cultural policy still dominates contemporary UK cultural funding (Miles 2013), despite various attempts to redress it (that we encounter in this chapter).

The current framework of UK cultural policy is indebted to the Victorians and their adoption of ideas of civilising as a way to a good society. Its management is more a history of institutions, and in 1940, the Council for the Encouragement of Music and the Arts (CEMA, to become the Arts Council of Great Britain) was established. It was World War II, and British cultural life-whether professional or amateur-was thought to be retracting, as described by Keynes cited earlier. The Board of Education intervened, saying it is essential 'to show publicly and unmistakably that the Government cares about the cultural life of this country' (cited in Hewison 1995, 30). The funding agreement committed CEMA to the 'preservation in wartime of the highest standards in the arts of music, drama and painting' and 'the widespread provision of opportunities for hearing good music and the enjoyment of the arts generally' (Hewison 1995, 33).

We can see that slippage between meanings of culture here cemented in a policy document from 80 -odd years ago. Where the idea of a broader 'cultural life' becomes synonymous with 'encouraging music and the arts', and that these are things 'the Government cares about'. As Hewison points out 'these essentially aristocratic, though benign, intentions are at odds with the democratic sentiments' (Hewison 1995, 33) of commentators like Raymond Williams who began questioning what and who culture was for. 
These concerns of whether people are accessing culture, and who has access, have become key questions for cultural policy. As we shall see, the Department for Culture, Media and Sport (DCMS) commissioned its own survey of 'characteristic activities and interests' (to quote T.S. Eliot again), to discover who is doing what. Yet, the model of government funding remains fixated on this link between the masses and masterpieces. ${ }^{10}$ Consequently, the institutions that formulate and deliver most of what we think of as cultural policy have become fanatical not only about ideas of cultural participation for its perceived personal and social benefits, but also how to fix 'non-participation', ${ }^{11}$ by engaging those who are not taking part. A cynic might say that this would allow the institutions of cultural policy to gain credibility for social impact and social change by way of simply getting those who are assumed to need more culture to enter their institutions, and we shall see how that plays out in data.

The deficit model of participation, and how many people are participating as an indicator of impact, is increasingly recognised as politically and empirically problematic. Cultural institutions are beginning to address the question: how are we deficient, if we are not engaging communities, rather than why are certain people not engaging with us? It is also important to note that cultural participation is a distant proxy measure of any form of social change. Entering a museum will not dissolve the social structures or traumatic experiences that leave some with ill-being or social disadvantage. So, counting heads of who enters institutions generates data with many limits, yet this method was the staple of data use for some time (as we will see in more detail in Sect. 6.3). To assume anyone who does not wish to participate in a cultural offer is deficient in some way is morally dubious at best and to prescribe particular activities as any sort of cure for social ills may even be argued to be irresponsible (Oman and Edwards 2020; Oman 2019a, b), misleading and misdirecting resources.

Well-being data have been used to plug the gap between attendance numbers and the capacity of cultural institutions to deliver social policy aims. Yet, in spite of years of investment, reams of theory, research and recent evolutions in data analysis, little has changed for the better (see Brook et al. 2020). We will return to how well-being data can be used to link the masses to masterpieces and help retain how the culture-well-being relationship remains institutionalised. However, we first of all need to return to questions of how certain aspects of culture are considered good for well-being in certain contexts. 


\section{Cultural Policy: Whose Culture Is Good Culture for Well-being?}

Sport and culture are widely perceived to generate social impacts. There is a long history of academic and evaluation research into the social impacts of sport and culture ... This evidence includes individual impacts (e.g. health/ fitness, mental health and wellbeing), life satisfaction, cognitive development, social skills; and broader community impacts such as social capital, increased volunteering, improved community cohesion, perceptions of quality of local area, increased educational performance, reduced crime/reoffending, reduced health care needs and economic development/ regeneration.

Sport is a broad and vague term that includes a wide range of activities.

Culture is defined as a broad term which encapsulates the arts, heritage and museums, libraries and archives. (The Culture and Sport Evidence Programme (CASE) Taylor et al. 2015)

We encountered how the naturalised relationship between culture and well-being is evident in the 2003 funding agreement between ACE and DCMS quoted at the beginning of this chapter, in which it committed to 'maximise and exploit the contribution of the arts to ... the well-being of the population at large' (DCMS 2003a, 15). DCMS distributed funding to a number of arm's length bodies in 2003, responsible variously for sport, the arts, heritage and museums and libraries and archives. The 2003 funding agreement articulated the idea that via ACE, the arts have a specific and mandated role in society. That role is to address societal issues, and in doing so, improve quality of life. Essentially, the arts should help people make the most of these activities to improve their well-being.

What happened to the concern over 'cultural life' more generally, you might ask? If culture is described in cultural policy research evaluations (such as this CASE ${ }^{12}$ example), as the activities attached to arts and cultural institutions, then what of the culture happening outside them? Why is this not also so for less institutionalised cultural engagement, recently labelled 'everyday participation' (Miles and Sullivan 2010)? CASE is 'a joint programme of strategic research led by DCMS in collaboration with Arts Council England, English Heritage and Sport England' (UK Government 2021). Originally a three-year-long project costing $£ 1.8$ million, reports have continued to be published under the CASE programme since.

Arguably two main things are going on in the way the CASE programme is framing culture. One might be that the institutionalising of 
certain forms of culture means that, by default, a social role must be found for such activities, if they are to receive government subsidy that could otherwise be distributed to other areas of social policy. Secondly, that evidence programmes were established in support of the activities managed by these institutions. So, more evidence is needed to justify the social role of culture, media and sport, in order to provide good reason for its subsidy. Crucially, evidence in support of these institutionalised areas is also more invested in (and more institutionalised) than broader cultural life.

The hierarchy of high art and leisure, or a more popular or vernacular culture, has been contested by cultural studies scholars such as Raymond Williams ([1958] 1989a) and Stuart Hall (various, see 1977 and McRobbie 2016). In the Leisure Studies literature, Stebbins' binary of 'casual leisure' and 'serious leisure' (Stebbins 1997, 1999) indicates that the latter is more 'important to the wellbeing [sic] of the individual and society', rather than largely non-productive leisure activities, such as 'hanging around' (cited in Blackshaw and Long 2005, 248). What are perceived to be bad choices and undesirable leisure pursuits remain a target for change, with personal and social 'happiness by design' (e.g. Dolan 2014) dominating the discourse of behavioural economics that includes many of the happiness economists we encountered in Chap. 4.

In policy terms, 'casual leisure' is often demonised. For example, the description of the 1999 reversal of Bhutan's national television ban ${ }^{13}$ includes a story of soaring crime, drug-taking and playground violence (Layard 2006, 78). Richard Layard explains that 'a third of parents now preferred watching TV to talking to their children', warning that the introduction of television as leisure coincided with the 'deteriorat[ion of] family relationships, the strength and safety of communities and the prevalence of unselfish values' (Layard 2006, 77, 78). ${ }^{14}$ Bhutan was the first nation to begin measuring what it calls 'gross national happiness' (GNH). In 1972, the Fourth King declared GNH to be more important than Gross National Product (GNP, similar to GDP), and from this time onward, the country oriented its national policy and development plans towards GNH. There is, of course, a longer history: the 1729 legal code, which dates from the unification of Bhutan, declared that if the Government cannot create happiness (dekid) for its people, there is no purpose for the Government to exist' (Ura 2010 via Helliwell et al. 2012, 111). Its measures incorporate the interdependence of aspects of wellbeing and the belief "that the beneficial development of human society 
takes place when material and spiritual development occurs side by side to complement and reinforce each other' (Helliwell et al. 2012, 111).

The story of Bhutan maintains a persistent place in narratives of the second wave of well-being which are otherwise Euro-American centric. However, the tale we are told is often partial. Bhutan's social and cultural life was idealised in descriptions of the importance of well-being measurement as a political and social project. The innovations of the Bhutanese happiness index were greatly praised. Yet, the domains and indicators themselves are rarely discussed. As Karma Ura, President of the Centre for Bhutan Studies and GNH research, explains:

The term subjective well-being, by which happiness is known in western literature, is telling. (Ura 2011, 1)

Ura is highlighting how happiness is an individualised concern in the West, rather than something oriented around an idea of society, and also pointing out that a fair society should be encouraged by: 'enlightenment education with respect to ethics, intellect and wisdom by its population in order to reach happiness (dewa)' (ibid., 2). He continues that social welfare accrues from 'unquantifiable spiritual and emotional well-being' (ibid., 2). Indeed, the Bhutanese well-being index has a whole domain called 'Cultural Diversity and Resilience', including 'native language', 'cultural participation', 'artisan skills' and 'conduct' (Helliwell et al. 2012, 115). In short, Bhutan's innovations in well-being measures incorporate many of the cultural aspects of social life that are missing from the other objective lists described in Chap. 3 from the likes of the OECD and the ONS.

Bhutan's attention to social and cultural life can be explained by the fact that-as a nation-it was less entrenched in the measurement and policy histories that informed many of the Euro-American approaches. They were therefore better equipped to capture 'culture' and 'well-being' without the institutional histories that Raymond Williams describes and as outlined in the evaluation research that opened this section. The question may not only be, 'why is Bhutan measuring different aspects of sociocultural life than OECD countries?' We might also ask the question, 'why are OECD countries so keen to follow Bhutan and measure well-being, but not follow how they are measuring well-being?' If we look at the wellbeing agenda more generally, we find a tendency to borrow (or appropriate) aspects of a different culture and adapt them. These modifications suit institutional histories of those doing the borrowing, indeed in the case of 
the wellness industry, to capitalise on them. This is the case of mindfulness (borrowed from Buddhism) and yoga, of course; Western versions of both of these cultural practices have been criticised for hollowing out their meaning, even disrespecting the beliefs of the cultures that have been borrowed from. ${ }^{15}$

To return to the narrative of television and Bhutan's happiness and leisure policy is, of course, informed by value judgements that preconceive what is 'good' leisure for individuals and society-and what is not. These value judgements are-of course-inherited. They are evidenced by Layard using statistics but interestingly, as noted in Chap. 4, White and Dolan (2009) found that time spent with children is relatively more rewarding than pleasurable, whereas time spent watching television is relatively more pleasurable than rewarding.

What is also interesting is that the reversal of the television ban (1999) happened but one year after GNH was announced as Bhutan's objective (Layard 2006, 77) and a few years before the indicators were developed. This marks a move from simply aiming for GNH, as the Fourth King aspired to in 1972, to actually measuring it. Bhutan was becoming less culturally closed to Western developments including the television-and social indicators. Ironically, Layard notes that the impact of television on Bhutan society 'provides a remarkable natural experiment in how technological change can affect attitudes and behaviour' (Layard 2006, 7), without acknowledging that measuring society to drive objectives will also lead to cultural and societal change. Well-being indicators being a good technological development and television not, we must assume, in this value system.

Choices over what is good for well-being and what has value in these terms are cultural decisions in their own right. This can be demonstrated in Bhutan's choice of indicators when compared to other decisions that we comprehensively covered in Chap. 3. It is also worth noting that the influential Sarkozy Commission that was established in 2007 and reported in 2009 (Stiglitz et al.) references the importance of cultural specificities and recommends that each nation find its own measures of well-being (Stiglitz et al. 2009, 18). Crucially, it is not only in the inclusion of a cultural domain that Bhutan differs, but also in the relationships drawn between social and cultural values within the structures of meaning that Williams advocates (cited earlier). Bhutan also included within its education indicator 'the cultivation and transmission of values' (Ura et al. 2012, 11) suggesting that these intertwined social, cultural and religious values are at 
the heart of the rationale for developing the GNH index in the first place. By contrast, social and cultural values held a precarious place in the project to establish the UK's well-being index, which we return to at the end of this chapter. For now, we must turn to how social value and cultural value each has a different meaning in UK social and cultural policy.

\section{Cultural Value and the Role of Well-being Data}

As with the terms culture, well-being and social value, you will probably not be surprised to know there is no one definition of cultural value. Like so many of the other terms set out in this book, there are long debates and no clear consensus (Oakley and O'Brien 2015). Given the extent of these discussions, there is a brief overview of cultural value, acknowledging how its definition and quantification became a much-discussed problem to resolve, safe in the knowledge that the detail of these debates can be found elsewhere. ${ }^{16}$

The impact of culture on the economy first became a prominent feature of cultural value in the last quarter of the twentieth century. The focus on efficiency of the 'Thatcherite revolution' (Power 1994) and new public management discussed in Chap. 2 saw a focus on 'social value' as a consideration in public decision-making. In parallel, what was called the 'economic turn' instigated new methodologies for measuring culture's worth as economic returns on investment (most notably Myerscough 1988). The new possibilities for measurement enabled by new methodologies, in turn, resulted in an increasing focus on measuring value, full stop, including areas of life less readily measurable than money.

Ideas of cultural value enable continuity from economic value to instrumental approaches to valuing what culture and leisure activities could do for both individuals and society. Under New Labour (1997-2010), this tended to be articulated more prominently as social value (harking back to Victorian values of social and moral improvement). However, in truth, there was a growing abundance of econometrics that were taken up as proxies for cultural value.

The Department for Culture, Media and Sport (DCMS, formerly Department for National Heritage) was renamed in 1997 by the then recently elected Tony Blair and was keen to promote the idea that 'sport and culture are widely perceived to generate social impacts' (Taylor et al. 2015,11 ), alongside economic impacts (see e.g. Hesmondhalgh et al. 2015). All New Labour departments inherited a civil service culture 
steeped in almost two decades of new public management approaches, mixing public and private provision and a commitment to using social science technologies to evaluate what worked and what did not in public administration (as discussed in Chap. 2).

Initially, the ways DCMS was required to assess its performance against social and economic goals were not demanding in terms of data or data expertise. As discussed above, it compared visitors to a range of events with the general population and used these numbers to make arguments about contributions to social aims. If the profile of people at these events grew closer to that of the general population-and less highly educated and white-then arguments were made for a contribution to social cohesion, as a 'strategic priority' (DCMS 2003b).

While not technically challenging, such assessments were hampered by the limits to the data available. It was impossible to identify how the fraction of the population going to a museum had changed in the last 12 months without a figure for the previous 12 months. The data collected on the cultural sector were partial, largely driven by specific targets generated by DCMS and related bodies. ${ }^{17}$ Thus, they reflected the interests and management approaches nationally, as well the expertise available. Cultural value arguments were increasingly included in the rhetoric of other actors and organisations, such as local authorities. These arguments retained the two key focusses: social impact and economic multipliers. If a local authority could show their local theatres led to economic growth, or to social impact, they could make a case for greater funding. Similarly, bids for new local arts venues ordinarily entailed commitments to an evaluation of economic and social impact.

Here we see the general 'enthusiasm for numbers' (Hacking 1991, 186; Hacking 2002) discussed in Chaps. 2 and 5, manifest in a need for data expertise in the cultural sector, which was lacking, because it had not been previously required. Consequently, there was an increasing reliance on consultancies to satisfy the desire for data and evidence for policy evaluation. This was symptomatic of a shift from collecting and describing data to a more involved analysis of the data gathered, as part of the production of evidence for valuing culture. Whereas researchers once 'collected and recorded mainly quantitative data on things like the number of creative or cultural businesses in a particular area, the number of people they employed, the amount of revenue they generated and other typically economic “indicators" of cultural and creative activity' (Prince 2015, 584), this work broadened, so that by 2010 , consultancies were estimating social 
and economic impact. This included bespoke data collection-for example, assessing the social impact of events by surveying attendees about changed perceptions (Prince 2015). It also increased the demand for understanding statistical power and significance (Prince 2014, 755). In short, the more research that was brought in, the more sophisticated it became, and the further outside the day-to-day remit of many responsible for evaluations.

Meanwhile, the need to ensure culture was part of discussions of valuation and appraisal encouraged further attempts to define cultural value. One of the most prominent is John Holden's $(2004,2006)$, for whom, there are different parts of society with different relations to, and needs for, culture. These different parts of society also reflect different perspectives on value: the public, the professionals and the politicians. Cultural value also takes three forms for Holden (2006), broadly representative of these groups. For example, 'intrinsic value' is the subjective experience of culture: 'intellectually, emotionally and spiritually' (Holden 2006, 14). 'Instrumental value' is how culture can be 'used to achieve social or economic purpose' (Holden 2006, 16). There is also 'institutional value' found in how people relate to cultural organisations. For example, the $\mathrm{BBC}$ was very concerned about its 'public value' and conducted a consultation so it could articulate its institutional value (in Holden's terms) to the public and its instrumental value in economic terms. ${ }^{18}$ ACE's 2007 Arts Debate aimed to fulfil a similar objective (Bunting 2007a, b). However, public consultation data may not always reinforce the values of institutions and can in fact challenge them. When reanalysing the ONS' data from the national well-being debate in 2010, I also found that Holden's three groups formulate the value of culture to well-being differently. The lack of reference to arts and cultural institutions in general or specific terms by people in these data (Oman 2020) poses important questions for the cultural value debate.

The problem of cultural value is also extrinsically linked to, yet separated from, economic value, in the policy context. Cultural economist David Throsby breaks cultural value down into different elements-aesthetic, spiritual, social, historic, symbolic and authenticity value-arguing that each contributes to the overall value of a cultural object, institution or experience (Throsby 2006, 42). He maintains that cultural value is separate from economic value and, relatedly, that 'there are some aspects of cultural value that cannot realistically be rendered in monetary terms' (Throsby 2006, 42). However, he also argues that a thorough economic 
valuation of both the market and non-market benefits of a cultural object can offer a good indication of its cultural value, because generally 'the more highly people value things for cultural reasons the more they will be willing to pay for' them (Throsby 2006, 42; see also 2010). Some aspects of cultural value lend themselves more readily to being expressed in the language of outputs and outcomes, whilst others do not. Given the valuation tools we have are predominantly from the field of economics, perhaps the one which is most readily measurable is economic value. This is because it is already numerical, in a way that people's subjective experiences are not.

As we can see, the idea of culture, the policies which contain and promote it, those who work in it, its infrastructure and research, seem to both attract and resist economic analysis. ${ }^{19}$ The proliferation of data collection and consultancy for policy appraisal included economic impact and valuation methodologies. Some of the economic valuation techniques that are used to capture the effects of culture are not yet technically sound (Rustin 2012), as will be expanded on in greater detail in the subsequent chapters (Chaps. 7 and 8). Yet, some argue the need to satisfy the demand for evidence of this kind of value has to be addressed in some way. One particular in-depth project focussed on how to overcome the gulf between what the cultural sector thought it was making culture for, and the demands of Her Majesty's Treasury (HMT) (O'Brien 2010). This report argued the need for pragmatism in presenting cultural value to secure public funding (O'Brien 2010, 8-9). It argued that 'the lack of consensus in the literature over the meaning of cultural value and how to best measure and capture cultural value suggests the potential of using established economic valuation tools' (O'Brien 2010, 15). By encouraging the sector to measure the value of culture in ways more acceptable to the hierarchies of evidence demanded by HMT, the report aimed to reconcile two cultures of evidencing cultural value. Arguably, however, this may have reinforced how very distinct they are, as well as leading to increased technocracy in the attempts of arts managers to do cultural economics or deal with more data.

Many in the sector see the value of their work as exceeding its economic value, and feel it cannot be reduced to economic considerations alone. Others argue that instrumentalising culture for social policy ends is not ethical for various reasons. It has also been pointed out that the hierarchies of cultural value (that one thing is more valuable than another to solve social problems) essentially 'define[] culture as a mechanism for the replication of inequality' (Oakley and O'Brien 2015, 5). These contestations have led to various audits of cultural value, such as the Warwick Commission 
for Cultural Value, which influentially cites Taylor's finding that the most privileged $8 \%{ }^{20}$ access culture (Taylor 2016, in Neelands et al. 2015). Arts Council England has commissioned numerous reviews on the subject, many of which ask for further evidence rather than using the evidence we already have. For example, the publication The Value of Arts and Culture to People and Society (ACE 2014) lists key themes of the value of culture as economy, health and well-being, society and education. Positioned as a rapid review of evidence, the report identifies a number of gaps, particularly regarding longitudinal data and the health and well-being evidence on cultural participation. Another example, the Arts and Humanities Research Council (AHRC) Cultural Value Project, a £2.5 million initiative over 3.5 years, supported over 70 original pieces of research initiated by the call, largely from arts and humanities research disciplines. The programme intended to improve comprehension of the value of arts and culture and the methods used to capture this value (Crossick and Kaszynska 2016). This programme has finished, but has resulted in a new Centre for Cultural Value which aims to build 'a shared understanding of the differences that arts, culture, heritage and screen make to people's lives and to society'. ${ }^{21}$

A recent large-scale academic project looked at how we might rearticulate 'cultural values' through understanding what people do in their everyday lives as culture, rather than thinking of cultural policy as something inherited to manage an elite idea of culture (Miles and Gibson 2016). Understanding Everyday Participation: Articulating Cultural Values (UEP) notably used many different types of data, collecting primary data using various methods, and analysing secondary data using different approaches. The premise was simple: understand what people were actually doing, and what they valued, rather than what cultural policymakers, the government, economists or the Happiness Tsar thought people should be doing (and then investing in programmes to get them to do what they thought people should be doing and measuring whether they did it, or not). Insights include dwindling investments in the social infrastructure presented by the local park (Gilmore 2017), or how charity shops in certain communities have been overlooked despite their specific 'relations between culture, economy and place which has effects in the social sphere' (Edwards and Gibson 2017).

As noted above, a particularly influential insight from UEP was through reanalysis of DCMS' Taking Part Survey data. Taylor found that: 
approximately $8.7 \%$ of the English population is highly engaged with statesupported forms of culture, and that this fraction is particularly well-off, well-educated, and white. Over half of the population has fairly low levels of engagement with state-supported culture but is nonetheless busy with everyday culture and leisure activities such as pubs, darts, and gardening. $(2016,169)$

Taking Part: The National Survey of Culture Leisure and Sport had been established in 2005 (DCMS 2006) as part of a programme of evidence generation led by DCMS. This new survey (known as Taking Part, and often shortened to TPS) aimed to collect data that would be useful to the concerns of all the sectors under DCMS' remit. Notably, the CASE programme cited above was also a part of this project. TPS asks detailed questions about what people do and where. Chapter 8 goes into greater detail about the wording of the questions, demonstrating the level of detail collected about simple pastimes, such as walking. The survey also collects demographic data and since the 2013-2014 dataset has also contained 'the ONS4' (see Table 4.3). TPS data therefore have inequality measures, well-being measures and highly detailed data about how people spend their time in terms of the variety of activities they undertake, how frequently and for how long. While DCMS have been criticised for not making enough of the survey data themselves (Bunting et al. 2019), others have analysed the data, looking at types of participation and inequality (Taylor 2016) and well-being (Fujiwara 2013; Fujiwara et al. 2015).

$\mathrm{My} \mathrm{PhD}$ research was connected to the UEP project, and as discussed in Chap. 3 and briefly here, one of my approaches used free text fields from the ONS' Measuring National Well-being Debate. My research presented a reordering of data to see how people value different domains of their life, in comparison to the published findings (Table 3.1). I found that when people talk about their well-being, they tend to describe the sorts of activities that Taylor lists, rather than those subsidised by cultural policy or indeed the institutions which house them. Overall, the vast body of research presented across the UEP project indicates the limits to research on and for cultural value arguments in asserting the value of particular forms of culture.

Most examples of articulating cultural value are attached to a specific idea of cultural policy (conflated here with arts policy), as you can see above. What is key here is that in deciding what is cultural in cultural value, cultural policy practitioners (policy-makers and academics) are also 
ascribing value to certain activities or practices. Much like the definition of social value and well-being, as described in Chap. 2 , this is a value system in and of itself: a ranking system which results in certain places, people and practices being invested in, while others are not. What is interesting is that what is thought to have caused the downfall of the social indicators movement in the 1970s was the 'bewildering array' of measures, as we discussed in Chap. 2. It was also the lack of a robust theoretical or ideological analysis, as well as the failure to establish what needed to be achieved for whom and how (Scott 2012,36). Despite the breakdown in prior measures, and years of contestation around the limitations of metricised cultural value, however, it remains a resilient idea that is heavily invested in.

\section{Well-being Measures: Arguing a Right to Culture?}

Everyone has the right freely to participate in the cultural life of the community, to enjoy the arts and to share in scientific advancement and its benefits. (Article 27 of the 1948 United Nations Universal Declaration of Human Rights)

Before the UK's well-being measures were finalised, a national debate was administered by the ONS to decide 'what matters to you?'. The first iteration of the national well-being measures (Beaumont 2012) did not account for culture. At the time, prominent commentators from the cultural sector expressed their dismay at this outcome, with one observer concluding in a national newspaper that this was proof that 'culture was invisible' to governments (Holden 2012). In actual fact, the omission was for various reasons; in part, because there was no validated measure for culture across the UK. ${ }^{22}$ But also, the ONS acknowledge the complexity of measuring multiple activities and wanted to avoid judgement on what should count and what not:

ONS considers that the currently proposed measures of satisfaction with the use and amount of leisure time should adequately reflect the effect of an individual's leisure time on their well-being without making a judgement that particular or specific activities are good for well-being. (Beaumont 2012, 15)

Avoiding judgement is worth reflecting on for a moment, when you think back to the discussions on who decides whose culture, and the 
Victorians putting museums 'into competition' with gin palaces, for example. Despite this disinclination to 'judge', in 2014, the ONS included one of DCMS' measures of culture from TPS in the national measures of well-being.

The metric is based on whether people have 'engaged with/participated in arts or cultural activity at least three times in the last year' and notably only covers England, rather than the whole UK. While it can be contested whether this maps directly on to Article 27 of the Declaration of Human Rights, cited above, the debate (Evans 2011; Oman 2020) and its subsequent public consultation (reported in Beaumont and Self 2012) demonstrate the social importance of a measure which included sociocultural concerns to the nation.

This makes it even more interesting to compare Bhutan's multiple measures for culture to the single indicator in the UK's well-being measures. We have encountered limitations on measuring domains of life that are relevant to well-being, and how the decisions of 'the metric makers' are largely down to deciding the metric is robust enough. The case study in Chap. 3 of the OECD composing its international index found a theoretical and moral commitment to including a measure of sustainability and yet, the measures of sustainability available were not robust enough.

There is an important tension in committing to understanding culture, community and sustainability, but arguing that these are too complex to capture. There may well be an argument that this is because these domains had not yet received the attention they deserved by Euro-American statisticians, despite the supposed influence of Bhutan. We might also wonder if it is the politicians who do not care for such domains (as Holden 2012 describes) or those who measure and research well-being?

Countering Holden's claims that culture has an invisibility problem (Holden 2012), cultural participation does feature in high-profile reports about well-being. As the influential Commission on the Measurement of Economic Performance and Social Progress highlights in its report, there is a long tradition of research emphasising the importance of leisure time for quality of life. 'This research points to the importance of developing indicators of both leisure quantity (number of hours) and quality (number of episodes, where they took place, presence of other people), as well as of measures of participation in cultural events and of "poor leisure"' (Stiglitz et al. 2009, 49).

In Europe, levels of 'access to cultural amenities was a significant predictor' of well-being in the countries measured by the European Quality of Life Survey (Chapple 2013, 98 ${ }^{23}$ ). However, the same report states that 
the accessibility of amenities does not independently predict life satisfaction. Instead, it has a positive impact on all other outcome variables, 'particularly reducing social exclusion and stress/busyness' (Chapple 2013, 52 ). Therefore, there is international recognition for the role of culture in attempts to both measure and understand well-being, but capturing this is complex, especially if it is not always fully interrogated.

The slippage of the meanings of culture we encountered earlier can also be found in Holden's exasperation that culture was not going to feature in the ONS' well-being measures. He uses a broad definition of culture in the same article in which he describes its (meaning the arts) invisibility to policy-makers (2012). These slippages might, in fact, be exacerbating the lack of attention to cultural indicators in larger statistical projects.

Culture and well-being are both 'complicated' words and attempts to capture either are contested-whether this is in their definition or in data. Similarly, value and values attract and resist the numeration and research that enable the persuasive arguments people want to make. This makes these insights valuable to different groups, creating a market for this research. The fact that Bhutan measures culture and values in multiple ways in its well-being index, when OECD countries do not, is important to take away from this chapter. Yet, when these are so difficult to define, slippage in meanings is exploited and national statistics offices want to avoid these sorts of judgements, it is difficult to see a way forward.

\subsection{Conclusion}

As we have seen, the naturalised role of cultural life as being valuable to a good society (or national and personal well-being) has been popularised in different parts of society and instrumentalised as policy. Yet articulations of cultural participation slip between everyday and elite activities, arguably confusing claims to social impact and understanding of what I call the culture-well-being relationship.

We have reflected on the theoretical lineage behind this naturalised relationship between culture and well-being. We have problematised assumptions, and shown the diversity of these claims for happiness, social justice or indeed hiding from social responsibility. The slippery nature of culture and well-being as concepts enables the relationship to morph to the needs of whoever chooses to invoke it, whether they are cultural commentators or policy-makers. This popularisation and instrumentalisation of the culture-well-being relationship is rife in cultural policy, and at a 
time in which the second wave of well-being and new valuation demands from Treasury affected demands for evidence, the relationship is increasingly reliant on well-being data and expertise.

The burden of proof is enmeshed with a historical tendency to decide what is good for (other) people's well-being, and what has social and cultural value. Such relations and values are not as fixed as these approaches assume. Of course, really, one would hope that all social policy areas impact on personal, social or community well-being in one way or another; otherwise they would not require social policy-making. Ironically, the idea that well-being measures can neutrally capture technological change without making their own technological changes is highly disputable when you consider the policy histories of Chap. 2. Data are cultural and they change culture and society in ways that are not acknowledged.

The Bhutanese well-being index has a rich cultural domain, with cultural values featuring in other domains, such as education. Yet, despite acknowledging Bhutan as an inspiration to measure well-being, few indices are inspired by the GNH indicators. In the UK, the current, single wellbeing indicator has a limited capacity to capture even arts participation at present-let alone a broader idea of social and cultural life. The following two chapters account for some issues in the 'evidence base' of evidencebased social and cultural policy. We interrogate data, how these are used to make arguments and how we might all be better equipped to interact with well-being data to understand culture and society for ourselves.

\section{Notes}

1. The Department of Culture, Media and Sport (DCMS) became the Department of Digital, Culture, Media and Sport in July 2017.

2. We will talk more about public value and cultural value later in this chapter, but if you want a refresher on social value, moral values and valuation, there is a section on it in Chap. 2.

3. Notably, operationalise means something slightly different in research, particularly quantitative research. Box 7.1 in Chap. 7 explains this further.

4. The academic literature looking at the process and effects of instrumentalisation are mixed. Gibson (2008) defends it, whilst many others who write on it talk of its damaging effects (i.e. Belfiore 2012; Hadley and Gray 2017).

5. The cultural value debate has been long-running, see: Crossick and Kaszynska (2016) for an overview.

6. The reliance on slavery to sustain this version of a good society, being just one. See footnotes 3 and 5 in Chap. 2 for further discussion and reading. 
7. Of course, you may find yourself noting the lack of consideration of a female reader by this 'man of letters'.

8. Other cultural studies scholars agree with this crucial point: Dick Hebdige explains that some groups have more opportunities to make more of the rules that organise 'meaning' as how we understand the world and each other through culture (1979). This he describes as hegemony, a term borrowed from Antoni Gramsci to account for how the dominance of certain groups of societies - their ideals, morals, values - and financial value - can be sustained over time. Stuart Hall (1977, cited in Hebdige 1979) explains that hegemony can only be maintained if the "dominant classes "succeed in framing all competing definitions within their range", so that subordinate groups are, if not controlled, then at least contained within an ideological space which does not seem at all "ideological" which appears instead to be permanent and 'natural' to lie outside history, to be beyond particular interests' (Hebdige 1979, 16).

9. For a recent take on Williams on this point, see Levine (2020).

10. Notably, for example, Arts Council England's ten-year strategy was called Achieving Great Art for Everyone (2010).

11. For discussion on issues with non-participation as an idea, see Stevenson (2016), and using Taking Part data, see Taylor (2016).

12. The CASE programme ran from 2008 and its outputs are hosted here https://www.gov.uk/guidance/case-programme\#case-programme-theresources, although only up until 2013, whereas the report cited in this chapter is from 2015. A special issue of the journal Cultural Trends reflected on the programme, and that publication is useful background to this story. See O'Brien (2012).

13. Until 1999 TV had been banned in Bhutan, as had public commercial advertising. Layard (2006) describes this in greater detail, acknowledging that we shouldn't generalise from one event.

14. There is a rich area of media studies which interrogates these assumptions about media consumption and 'deviance' (i.e. Eithne Quinn's work on hip hop, 2020). While Bhutan's case is an interesting 'test' environment, as it had not previously had television, other studies using longitudinal data have been unable to substantiate a link (i.e. Shi et al. 2019).

15. See Purser's (2019) critiques of 'McMindfulness'.

16. For example, in: O'Brien (2010); Oakley and O'Brien (2015); Crossick and Kaszynska (2016); Neelands et al. (2015).

17. See Selwood (2002) for a comprehensive review of cultural sector data.

18. O'Brien $(2013,122-130)$ covers particular case studies of public value in greater detail.

19. See Doyle (2010) for a longer discussion on how culture attracts and resists economics. 
20. Note it was actually $8.7 \%$, but was unconventionally rounded down in error to $8 \%$ when the finding was reproduced. See Taylor $(2016)$ for more detail on the actual findings.

21. The Arts and Humanities Research Council (AHRC), Paul Hamlyn Foundation (PHF) and Arts Council England (ACE) jointly funded this call to establish a Centre for Cultural Value (CCV) to the value of up to $£ 2$ million (University of Leeds n.d.). The new centre is hosted at the University of Leeds.

22. This was partly because the work to include indicators for culture (e.g. within local authority Best Value performance indicators that had been significantly invested in during the New Labour period) was erased with the removal of such performance management strategies by the incoming Coalition government in 2010. See Gilmore (2014) for further discussion.

23. The report does not explicitly outline how 'access to cultural amenities was a significant predictor' of well-being, however. Furthermore, the question about amenities in the survey, which allows the authors to arrive at this policy recommendation, is: 'Access to amenities (including postal services, bank, public transport, culture, green space)' (Chapple 2013, 106). Green space is the most important predictor, but the report is not clear on the degree to which access to cultural amenities predicts well-being.

\section{REFERENCES}

ACE. 2007. Strategy for the Arts Health and Wellbeing. London: Arts Council England, p. 52. Accessed 29 April 2021. https://www.artshealthresources.org. uk/wp-content/uploads/2017/01/2007-ACE-Strategy-for-the-arts-healthand-wellbeing.pdf.

. 2009. Annual Review 2009. London: Arts Council England, p. 160. Accessed 28 April 2021. https://www.artscouncil.org.uk/sites/default/files/ download-file/Review\%20-\%20Arts\%20Council\%20England\%20Annual\%20 Review\%202009.pdf.

- 2014. The Value of Arts and Culture to People and Society. Arts Council England. Accessed 28 April 2021. https://www.artscouncil.org.uk/publication/value-arts-and-culture-people-and-society.

AHRC. 2021. Arts and Health, Health and Wellbeing Research Portfolio. Accessed 29 April 2021. https://ahrc.ukri.org/innovation/health-and-wellbeingresearch-portfolio/arts-and-health/.

AHSW. n.d.. Arts \& Health South West, Arts \& Health South West-Home. Accessed 29 April 2021. https://www.ahsw.org.uk/

All-Party Parliamentary Group on Arts, Health and Wellbeing. 2014. Creative Health: The Arts for Health and Wellbeing. Accessed 28 April 2021. https:// www.culturehealthandwellbeing.org.uk/appg-inquiry/. 
Beaumont, J. 2012. Measuring National Well-Being: A Discussion Paper on Domains and Measures. Office for National Statistics. http://webarchive. nationalarchives.gov.uk/20160106195224/http://www.ons.gov.uk/ons/ dcp171766_240726.pdf.

Beaumont, J., and Self, A. 2012. Initial Findings from the Consultation on Proposed Domains and Measures of National Well-being. London: ONS.

Belfiore, E. 2012. "Defensive instrumentalism" and the legacy of New Labour's cultural policies. Cultural Trends 21 (2): 103-111. https://doi.org/10.1080/ 09548963.2012.674750.

Belfiore, E., and O. Bennett. 2008. The Social Impact of the Arts: An Intellectual History. Basingstoke and New York: Palgrave Macmillan.

Bennett, T. 2000. Acting on the Social: Art, Culture, and Government. American Behavioral Scientist 43 (9): 1412-1428. https://doi.org/10.1177/ 00027640021955964.

Blackshaw, T., and J. Long. 2005. What's the Big Idea? A Critical Exploration of the Concept of Social Capital and its Incorporation into Leisure Policy Discourse. Leisure Studies 24 (3): 239-258. https://doi.org/10.108 0/0261436052000327285.

Brook, O., D. O'Brien, and M. Taylor. 2020. Culture Is Bad for You: Inequality in the Cultural and Creative Industries. Manchester: Manchester University Press.

Bunting, C. 2007a. Public Value and the Arts in England: Discussion and Conclusions of the Arts Debate. Arts Council England. https://www.a-n.co.uk/ research/public-value-arts-england-discussion-conclusions-arts-debate/.

- 2007b. The Arts Debate: Stage One Findings and Next Steps. London: Arts Council England. http://www.artscouncil.org.uk/artsdebate/ArtsDebate_ ACE_stagel_report.pdf.

Bunting, C., A. Gilmore, and A. Miles. 2019. Calling Participation to Account: Taking Part in the Politics of Method. In Histories of Cultural Participation, Values and Governance, ed. E. Belfiore and L. Gibson, 183-210. London: Palgrave Macmillan UK (New Directions in Cultural Policy Research). https:// doi.org/10.1057/978-1-137-55027-9_8.

Campbell, P. 2019. Persistent Creativity: Making the Case for Art, Culture and the Creative Industries. Palgrave Macmillan (Sociology of the Arts). https://doi. org/10.1007/978-3-030-03119-0.

Chapple, S. 2013. Subjective Well-Being and Social Policy. European Commission. Crossick, G., and P. Kaszynska. 2016. Understanding the Value of Arts \& Culture: The AHRC Cultural Value Project. Swindon: AHRC.

DCMS. 2003a. Funding Agreement between Arts Council England and the Department for Culture, Media and Sports, April 2003-March 2006. Department for Culture, Media and Sport.

. 2003b. Strategic Plan 2003-2006. London: Department for Culture, Media and Sport. 
2004. Culture at the Heart of Regeneration. Department for Culture, Media and Sport.

- 2006. Taking Part: The National Survey of Culture, Leisure and Sport, 2005-2006; Adult and Child Data [Data Collection]. 2nd ed. SN: 5717. UK Data Service. https://doi.org/10.5255/UKDA-SN-5717-1.

- 2011. Creative Industries Economic Estimates. Department for Digital, Culture, Media \& Sport. https://www.gov.uk/government/collections/ creative-industries-economic-estimates.

Dolan, P. 2014. Happiness by Design: Finding Pleasure and Purpose in Everyday Life. London: Penguin Books.

Doyle, G. 2010. Why Culture Attracts and Resists Economic Analysis. Journal of Cultural Economics 34 (4): 245-259. https://doi.org/10.1007/ s10824-010-9128-9.

Edwards, D., and L. Gibson. 2017. Counting the Pennies: The Cultural Economy of Charity Shopping. Cultural Trends 26 (1): 70-79. https://doi.org/10.108 0/09548963.2017.1275131.

Evans, J. 2011. Findings from the National Well-being Debate. Office for National Statistics. https://docplayer.net/66842-Joanne-evans-office-for-national-statistics.html Accessed 10 August 2021.

Fujiwara, D. 2013. Museums and Happiness: The Value of Participating in Museums and the Arts. United Kingdom: The Happy Museum; Museum of East Anglian Life; Arts Council England. Accessed 29 March 2021. https://happymuseumproject.org/wp-content/uploads/2013/04/Museums_and_happiness_ DFujiwara_April2013.pdf

Fujiwara, D., P. Dolan, and R. Lawton. 2015. Creative Occupations and Subjective Wellbeing. 15(9). https://media.nesta.org.uk/documents/creative_employment_and_subjective_wellbeing_1509_1.pdf.

Gibson, L. 2008. In defence of instrumentality. Cultural Trends 17 (4): 247-257. https://doi.org/10.1080/09548960802615380

Gilmore, A. 2014. Raising Our Quality of Life: The Importance of Investment in Arts and Culture. CLASS (Centre for Labour and Social Studies. Accessed 28 April 2021. http://classonline.org.uk/docs/2014_Policy_Paper_-_investment_in_the_arts_-_Abi_Gilmore.pdf.

- 2017. The Park and the Commons: Vernacular Spaces for Everyday Participation and Cultural Value. Cultural Trends 26 (1): 34-46. https://doi. org/10.1080/09548963.2017.1274358.

Gilmore, A., and P. Doyle. 2019. Histories of Public Parks in Manchester and Salford and Their Role in Cultural Policies for Everyday Participation. In Histories of Cultural Participation, Values and Governance, ed. E. Belfiore and L. Gibson, 129-152. London: Palgrave Macmillan UK (New Directions in Cultural Policy Research). https://doi.org/10.1057/978-1-137-55027-9_6. Hacking, I. 1991. How Should We Do the History of Statistics? In The Foucault Effect: Studies in Governmentality, ed. G. Burchell, C. Gordon, and P. Miller. Chicago: The University of Chicago Press. 
. 2002. Making Up People. In Historical Ontology. Cambridge, MA: Harvard University Press.

Hadley, S., and C. Gray. 2017. Hyperinstrumentalism and Cultural Policy: Means to an End or an End to Meaning? Cultural Trends 26 (2): 95-106. https:// doi.org/10.1080/09548963.2017.1323836.

Hall, S. 1977. Culture, the Media, and the 'Ideological Effect'. In Essential Essays. Durham: Duke University Press.

Hebdige, D. 1979. Subculture: The Meaning of Style. London: Methuen.

Helliwell, J.F., R. Layard, and J. Sachs. 2012. World Happiness Report [2012]. Vancouver: University of British Columbia Library. Accessed 28 April 2021. http://hdl.handle.net/2429/44498.

Hesmondhalgh, D., Oakley, K., Lee, D., and Nisbett, M. 2015. Culture, Economy and Politics: The Case of New Labour. Palgrave MacMillan.

Hewison, R. 1995. Culture and Consensus: England, Art and Politics since 1940. London: Methuen.

Holden, J. 2004. Capturing Cultural Value: How Culture Has Become a Tool of Government Policy. London: Demos.

- 2006. Cultural Value and the Crisis of Legitimacy: Why Culture Needs a Democratic Mandate. London: Demos.

— 2012. New Year, New Approach to Wellbeing?, The Guardian. https:// www.theguardian.com/culture-professionals-network/culture-professionalsblog/2012/jan/03/arts-heritage-wellbeing-cultural-policy.

Janaway, C. 1994. Schopenhaner. Oxford: Oxford University Press.

Jowell, T. 2004. Government and the Value of Culture. London: HMSO/DCMS.

Kant, I. [1790]1987. Critique of Judgment. Translated by W.S. Pluhar. Indianapolis: Hackett Publishing Company.

Keynes, J.M. 1945. The Arts Council: Its Policy and Hopes. In The Collected Writings of John Maynard Keynes, ed. D. Maggridge, 367-372. London: Macmillan.

Layard, R. 2006. Happiness: Lessons from a New Science. Penguin.

Levine, C. 2020. Raymond Williams, Marxism and Literature (1977). Public Culture 32 (2 (91): 423-430.

LGA. 2020. Cultural Strategy in a Box. Local Government Association.

McRobbie, A. 2016. Stuart Hall: Art and the Politics of Black Cultural Production. South Atlantic Quarterly 115 (4): 665-683. https://doi.org/10.121 5/00382876-3656081.

Miles, A. 2013. Culture, Participation and Identity in Contemporary Manchester. In Culture in Manchester: Institutions and Urban Change since 1850, ed. J. Wolff and M. Savage, 176-193. Manchester and New York: Manchester University Press.

Miles, A., and L. Gibson. 2016. Everyday Participation and Cultural Value. Cultural Trends 25 (3): 151-157. https://doi.org/10.1080/0954896 3.2016.1204043. 
Miles, A., and A. Sullivan. 2010. Understanding the Relationship between Taste and Value in Culture and Sport. London: DCMS.

Myerscough, J. 1988. The Economic Importance of the Arts in Britain. London: Policy Studies Institute.

National Endowment for the Arts. 2018. The Arts Contribute More Than $\$ 760$ Billion to the U.S. Economy. https://www.arts.gov/news/2018/ arts-contribute-more-760-billion-us-economy.

Neelands, J., et al. 2015. Enriching Britain: Culture, Creativity and Growth: The 2015 Report by the Warwick Commission on the Future of Cultural Value. Warwick: The University of Warwick. https://warwick.ac.uk/research/warwickcommission/futureculture/finalreport/warwick_commission_ report_2015.pdf.

O'Brien, D. 2010. Measuring the Value of Culture: A Report to the Department for Culture Media and Sport. DCMS.

- 2012. CASE: The Culture and Sport Evidence Programme (Special Issue). Cultural Trends 21 (4): 0954-8963. https://doi.org/10.108 0/09548963.2012.726788.

- 2013. Cultural Policy: Management, Value and Modernity in the Creative Industries. New York: Routledge.

Oakley, K., and D. O'Brien. 2015. Cultural Value and Inequality: A Critical Literature Review. Arts and Humanities Research Council; The University of Leeds. https://eprints.whiterose.ac.uk/88558/.

Oman, S. 2019a. How Do You Manage with Loneliness? Observations from the Field: Problematising Participation as the Solution to Loneliness, presentation at Thinking and Measuring Loneliness across the Life Course. 12 June 2019, Manchester Metropolitan University. Available at: https://www.lonelinessconnectsus.org/blog/thinking-and-measuring-loneliness-across-the-life-course.

- 2019b. Problematising Participation as the Policy Solution to 'Combat Loneliness': Policy Paper.

- 2020. Leisure Pursuits: Uncovering the 'Selective Tradition' in Culture and Well-being Evidence for Policy. Leisure Studies 39 (1): 11-25. https://doi. org/10.1080/02614367.2019.1607536

Oman, S., and D. Edwards. 2020. Temporalities and Typologies of Loneliness: A Methodology to Understand New Parents, Self-Predicted Loneliness \& the Role of NCT. In Loneliness \& Social Isolation in Mental Health Research Network Symposium. London. https://www.ucl.ac.uk/psychiatry/ events $/ 2020 /$ jan/loneliness-social-isolation-mental-health-researchnetwork-symposium.

Oman, S., and M. Taylor. 2018. Subjective Well-Being in Cultural Advocacy: A Politics of Research between the Market and the Academy. Journal of Cultural Economy 11 (3): 225-243. https://doi.org/10.1080/1753035 0.2018 .1435422 . 
ONS. 2011. Measuring National Well-Being Technical Advisory Group. Office for National Statistics. Accessed 5 April 2014. http://www.ons.gov.uk/ons/ guide-method/user-guidance/well-being/measuring-national-well-beingtechnical-advisory-group/Notes-from-the-meeting-on-4-february-2011.pdf.

Power, M. 1994. The Audit Society. In Accounting as Social and Institutional Practice, ed. A. Hopwood and P. Miller, 299-316. Cambridge: Cambridge University Press.

Prince, R. 2014. Calculative Cultural Expertise? Consultants and Politics in the UK Cultural Sector. Sociology 48 (4): 747-762. https://doi. org/10.1177/0038038513502132.

- 2015. Economies of Expertise: Consultants and the Assemblage of Culture. Journal of Cultural Economy 8 (5): 582-596. https://doi.org/1 $0.1080 / 17530350.2014 .974654$.

Purser, R. 2019. McMindfulness: How Mindfulness Became the New Capitalist Spirituality. Repeater Books.

Rustin, S. 2012. The Conversation: Can Happiness be Measured?, The Guardian. Accessed 28 April 2021. https://www.theguardian.com/commentisfree $/ 2012 / j u l / 20 /$ wellbeing-index-happiness-julian-baggin.

Schopenhauer, A. 1818. The World as Will and Representation. Translated by E.F.J. Payne. New York: Dover.

Scott, K. 2012. Measuring Wellbeing: Towards Sustainability? London: Routledge. https://www.taylorfrancis.com/https://www.taylorfrancis.com/books / mono/10.4324/9780203113622/measuring-wellbeing-towardssustainability-karen-scott.

Selwood, S. 2002. The Politics of Data Collection: Gathering, Analysing and Using Data about the Subsidised Cultural Sector in England. Cultural Trends 12 (47): 13-84. https://doi.org/10.1080/09548960209390330.

- 2010. Making a Difference: The Cultural Impact of Museums. London: NMDC.

Shi, L., S.P. Roche, and R.M. McKenna. 2019. Media Consumption and Crime Trend Perceptions: A Longitudinal Analysis. Deviant Behavior 40 (12): 1480-1492. https://doi.org/10.1080/01639625.2018.1519129.

Stebbins, R.A. 1997. Casual Leisure: A Conceptual Statement. Leisure Studies 16 (1): 17-25. https://doi.org/10.1080/026143697375485.

Stebbins, R. 1999. Serious Leisure. In Leisure Studies Prospects for the Twenty-First Century, ed. E.L. Jackson and T.L. Burton, 69-80. Philadelphia: Venture Publishing.

Stevenson, D.J. 2016. Understanding the Problem of Cultural Non-Participation: Discursive Structures, Articulatory Practice and Cultural Domination. Thesis. Queen Margaret University, Edinburgh. Accessed 29 April 2021. https://eresearch.qmu.ac.uk/handle/20.500.12289/7339. 
Stevenson, D. 2019. The Cultural Non-Participant: Critical Logics and Discursive Subject Identities. Arts and the Market9 (1): 50-64. https://doi.org/10.1108/ AAM-01-2019-0002.

Stiglitz, J.E., A. Sen, and J.-P. Fitoussi. 2009. Report by the Commission on the Measurement of Economic Performance and Social Progress. OECD. https:// ec.europa.eu/environment/beyond_gdp/download/CMEPSPfinal-eport.pdf.

Taylor, M. 2016. Nonparticipation or Different Styles of Participation? Alternative Interpretations from Taking Part. Cultural Trends 25 (3): 169-181. https:// doi.org/10.1080/09548963.2016.1204051.

Taylor, P., et al. 2015. A Review of the Social Impacts of Culture and Sport, 136. Department for Culture, Media and Sport.

Throsby, D. 2006. The Value of Cultural Heritage: What Can Economics Tell Us? In Capturing the Public Value of Heritage: The Proceedings of the London Conference. Capturing the Public Value of Heritage, 40-43. Swindon: English Heritage. Accessed 28 April 2021. https://researchers.mq.edu.au/en/publications/the-value-of-cultural-heritage-what-can-economics-tell-us.

- 2010. The Economics of Cultural Policy. Cambridge: Cambridge University Press.

UK Government. 2021. CASE Programme Guidance and Resources, National and Official Statistics. Accessed 28 April 2021. https://www.gov.uk/guidance/ case-programme.

UNESCO. 2018. RURITAGE: Rural Regeneration through Systemic HeritageLed Strategies, UNESCO. Accessed 28 April 2021. https://en.unesco. org/ruritage.

United Nations. 1948. Universal Declaration of Human Rights, United Nations. United Nations. Accessed 28 April 2021. https://www.un.org/en/about-us/ universal-declaration-of-human-rights.

University of Leeds. n.d. Centre for Cultural Value. School of Performance and Cultural Industries. https://ahc.leeds.ac.uk/centre-cultural-value-1.

Ura, K. 2011. The Bhutanese Development Story. Centre for Bhutan \& GNH Studies. Accessed 28 April 2021. https://www.bhutanstudies.org.bt/publicationFiles/Monograph/mono-len-bt-dev-stry.pdf.

Ura, K., S. Alkire, and T. Zangmo. 2012. GNH and GNH Index. Centre for Bhutan Studies. Accessed 28 April 2021. https://ophi.org.uk/wp-content/ uploads/GNH_and_GNH_index_2012.pdf.

Williams, R. [1958]1989a. Culture Is Ordinary. In Resources of Hope: Culture, Democracy, Socialism, ed. R. Gable. London and New York: Verso.

- [1961]1971. The Long Revolution. London: Pelican. 1977. Marxism and Literature. Oxford: Oxford University Press.

- [1976]1988. Keywords: A Vocabulary of Culture and Society. 2nd ed. London: Fourth Estate Ltd. 
Open Access This chapter is licensed under the terms of the Creative Commons Attribution 4.0 International License (http://creativecommons.org/licenses/ by $/ 4.0 /$ ), which permits use, sharing, adaptation, distribution and reproduction in any medium or format, as long as you give appropriate credit to the original author(s) and the source, provide a link to the Creative Commons licence and indicate if changes were made.

The images or other third party material in this chapter are included in the chapter's Creative Commons licence, unless indicated otherwise in a credit line to the material. If material is not included in the chapter's Creative Commons licence and your intended use is not permitted by statutory regulation or exceeds the permitted use, you will need to obtain permission directly from the copyright holder. 